\title{
A Multi-Dimensional Analysis of Corporate Social Responsibility: The Liquidity Risk Factor
}

\author{
Homayoon Shalchian ${ }^{1}$, Bouchra M'Zali² $^{2}$, Hager Tebini ${ }^{2}$ \\ ${ }^{1}$ Laurentian University, Ontario, Canada \\ ${ }^{2}$ University of Quebec at Montreal, Montreal, Canada \\ Email: *hshalchian@laurentian.ca
}

How to cite this paper: Shalchian, H., M'Zali, B., \& Tebini, H. (2018). A Multi-Dimensional Analysis of Corporate Social Responsibility: The Liquidity Risk Factor. Journal of Financial Risk Management, 7, 241-253. https://doi.org/10.4236/jfrm.2018.73016

Received: March 8, 2018

Accepted: September 18, 2018

Published: September 21, 2018

Copyright (c) 2018 by authors and Scientific Research Publishing Inc. This work is licensed under the Creative Commons Attribution International License (CC BY 4.0).

http://creativecommons.org/licenses/by/4.0/

cc) (i) Open Access

\begin{abstract}
This study is an extension to Shalchian et al. (2015) and investigates the effect of the "liquidity" risk factor on the performance of socially responsible investments in different industries and based on different dimensions of corporate social responsibility. Using Pastor and Stambault's liquidity risk factor, we find that in the mining industry and based on the dimensions of "environment", "employees' relations" and "community involvement", socially responsible investments are relatively less exposed to the liquidity risk factor. Our results also suggest that compared to conventional investments in the manufacturing and service industries, socially responsible investment's performance is more sensitive to the liquidity risk factor.
\end{abstract}

\section{Keywords}

Corporate Social Responsibility, Liquidity Risk Factor, Financial Performance

\section{Introduction}

During the past two decades, socially responsible investment (SRI) has known a significant growth and investors have increasingly incorporated social and environmental criteria in their investment decisions (Kempf \& Osthoff, 2007; El Ghoul et al., 2011). For scholars, SRI has been a very popular field of study and the main question has been whether corporate social performance (CSP) creates an additional value for investors (Goss \& Roberts, 2011). Numerous academic studies associate a positive abnormal return for SRI (Yamashita et al., 1999; Derwall et al., 2005; Kempf \& Osthoff, 2007; Shalchian et al., 2012, 2014); however, socially responsible investment and its premium remain a puzzle for academicians and investors.

The relation between corporate social performance and investors' financial 
performance has been investigated using different measures of CSP and different samples (Shalchian et al., 2015). While several studies consider "mixed" samples of companies (Derwall et al., 2005; Shalchian et al., 2012), others focus on one specific sector of an industry (Moore, 2001; Simpson \& Kohers, 2002). Moreover, several studies use one specific dimension of CSP (Cohen et al., 1997; Yamashita, 1999; Derwall et al., 2005) while others use multi-dimensional measures of social responsibility (Kempf \& Osthoff, 2007; Shalchian et al., 2012). On the issues of dimensions of social responsibility and sector of industry, Shalchian et al. (2015) bring an improvement to prior studies by investigating the relation between different dimensions of CSP and investors' financial performance in different industries. Their results suggest that different dimensions of CSP have different impacts on abnormal returns on stocks in different industries.

Financial literature also suggests that stock returns can be affected by other risk factors such as "Liquidity". Brennan and Subrahmanyam (1996) and Fiori (2000), Chordia et al. (2001), using "micro-measures" of liquidity, find that expected returns across financial assets are correlated with the liquidity risk factor. Other studies such as Holmstrom and Tirole (2001), using an aggregate measure of liquidity, show that stocks' expected returns are related to the liquidity risk factor. Similarly, Pastor and Stambault (2003) show that expected stock returns are related to the fluctuations in aggregate liquidity.

The objective of this study is to investigate whether the relation social-financial performance is related to the liquidity risk factor. More specifically, using stock performance in Shalchian et al. (2015), and Pastor and Stambault's measure of liquidity, we verify whether the performance of socially responsible investments relative to conventional investments can be affected by the liquidity risk factor.

This paper is organized as follows. In the next section, we present the theoretical framework for socially responsible investments and the liquidity risk factor. Section 3 and 4 present, respectively, the database and our methodology. We present our results and conclusions in Section 5 and 6.

\section{Theoretical Framework}

Financial theory has analyzed the relation between financial performance and the liquidity risk factor (Brennan \& Subrahmanyam, 1996; Fiori, 2000; Chordia et al., 2001; Pastor \& Stambault, 2003). A body of theory has also analyzed the performance of socially responsible investments. Several studies analyze the associated risk (Robinson et al., 2008; Starks, 2009; El Ghoul et al., 2011; Bouslah et al., 2013) while others examine the financial performance, adjusted for the risk, of socially responsible investments (Derwall et al., 2005; Kempf \& Osthoff, 2007; Shalchian et al., 2012, 2014, 2015).

\subsection{The Liquidity Risk Factor and Investment}

A body of theory suggests that fluctuations in various measures of liquidity are 
correlated across assets and affect the volatility of stocks' returns (Lo \& Wang, 2000; Huberman \& Halka, 2001; Pastor \& Stambault, 2003). For instance, Lo and Wang (2000) develop a dynamic equilibrium model and show that volume, prices and other state variables evolve through time together. Also, Eisfeldt (2002) presents a model in which fluctuations in liquidity are correlated with investment. More specifically, Eisfeldt (2002) argues that since liquidity makes long-term risky investments more attractive, it amplifies the effect of changes in productivity on volume and on investment. Similarly, Huberman and Halka (2001) suggest that temporal variation in the liquidity proxies affects stock returns positively but affects the volatility negatively. Other studies such as Brennan and Subrahmanyam (1996), Fiori (2000) and Chordia et al. (2001), using different measures of liquidity, find a negative relation between liquidity and expected returns. Several studies have also focused on the correlation between aggregate liquidity and stock returns. For instance, Holmstrom and Tirole (2001), using an aggregate measure of liquidity, show that stocks' expected returns are related to their covariance with liquidity. Similarly, Pastor and Stambault (2003) investigate whether expected stock returns are related to the fluctuations in aggregate liquidity. In their study, they construct a measure of market liquidity as the equally weighted average of the liquidity measures of individual stocks on NYSE and AMEX. Their results suggest that investors require relatively higher expected returns on assets whose returns have higher sensitivities to aggregated liquidity.

\subsection{Socially Responsible Investment and the Level of Risk}

Prior research on the performance/risk of SRI can be divided into two categories. A first category analyzes firm's irresponsible actions and their impact on investments' risk. For instance, Robinson et al. (2008) and Starks (2009) analyze the impact of corporate social irresponsibility on the firm's risk. Their results suggest that firms with socially irresponsible practices seem to have a relatively higher level of risk. Similarly, Shalchian et al. (2015) also suggest that investors perceive an additional risk and, consequently, eventual financial losses due to the firm's socially irresponsible actions. Waddock and Graves (1997) argue that investors anticipating additional future costs related to the firm's social irresponsibility, perceive a relatively higher level of risk for their investment. Further, a second category of study analyzes firm's socially responsible actions and their relation with the risk perceived by investors. For instance, Shalchian et al. (2014), using a theoretical framework, show that CSP affects the risk of socially responsible firms. Their results suggest that perception of CSP by the investor results in a change of the combination risk/return of the financial assets. Moreover, several empirical studies such as El Ghoul et al. (2011) and Bouslah et al. (2013) show that firms with socially responsible practices have a relatively lower level of risk. El Ghoul et al. (2011) also suggest that the relatively lower level of risk results in a relatively lower cost of equity and consequently a higher market 
valuation of socially responsible firms.

Prior research on the risk of SRI can also be divided into two categories based on the measures of social performance. Several studies use individual dimensions of CSP. For instance, Bauer, Derwall and Hann (2009) examine the relation between the dimension "employees' welfare" and the firm's risk. Their results suggest that firms with better employee relations have relatively lower levels of risk and higher credit rates. Similarly, Salama et al. (2011) suggest that firms with socially responsible practices with respect to the environment and community seem to have a relatively lower level of risk. Harrisson and Freeman (1999) argue that in these cases there is no mention of how these companies perform with respect to other dimensions of social responsibility. Similarly, Stanwick and Stanwick (1998) argue that social performance is a multi-dimensional concept and studies on the relation should take various dimensions into consideration. Reinforcing this point, a second category of study uses aggregate measures of CSP. For instance, Lee and Faff (2009), Goss (2012), using aggregate measures of social performance find negative relations between CSP and a firm's level of risk. Similarly, Shalchian et al. (2012), analyze the relation between external dimensions (combination of environment, community, product, human rights and exclusionary screens) and internal dimensions (combination of employee relations, governance and diversity) of CSP with the performance, adjusted for risk, of socially responsible investments. Their results suggest that external components of CSP seem to result in a relatively higher financial performance of socially responsible investments. Concerning the dimensions of CSP, Kempf and Osthoff (2007) and Bouslah et al. (2013) bring a significant improvement to prior studies. Analyzing several individual dimensions of CSP, Kempf and Osthoff (2007) show that different components of social performance have different impacts on the performance, adjusted for the risk, of socially responsible investments. Similarly, Bouslah et al. (2013), considering several dimensions of CSP separately, find different relations between individual dimensions of CSP and a firm's level of risk.

Finally, prior research on the subject can be divided into two categories based on sampled firms. Several studies use mixed samples from different industries (Waddock \& Graves, 1997; Chung et al., 2003). Derwall et al. (2005), using the Fama and French industry factor, show that the relation social-financial performance tends to be industry-sensitive. Reinforcing this point, several studies use sampled firms from specific industries. For instance, Simpson and Kohers (2002) concentrate their study on the banking industry while Moore (2001) finds a negative relation between social and financial performance in the supermarket industry. Further, Griffin and Mahon (1997) suggest that social issues can change from one industry to another based on the nature of each firm's activities. Reinforcing this point, Shalchian et al. (2015) investigate the relation between individual dimensions of CSP when examined separately with financial performance, adjusted for the risk, in different industries. Their results suggest 
that environmentally responsible firms in the mining and manufacturing industries seem to perform better than their conventional counterparts while firms with respect for "employees' welfare" show a better financial performance, adjusted for the risk, than their conventional counterparts in the service industry.

In this paper, we attempt to examine the effect of a liquidity risk factor on the performance of socially responsible investments. Using the portfolios' returns in Shalchian et al. (2015) and Pastor and Stambault's liquidity risk factor, we verify whether the financial performance of socially responsible investments based on different dimensions of CSP and in different industries is correlated with the risk of liquidity.

\section{Data}

In this study, we obtain social ratings from MSCI-KLD (formerly known as KLD). The database includes approximately 3000 firms since 2003 and evaluates companies for several social criteria (environment, employees' relation, community, diversity, human rights, product, governance and exclusionary screens). For each social criteria, KLD uses multiple sub-criteria that can be divided into "strength" (positive social actions) and "concerns" (negative social actions). For example, one of KLD's criteria for the dimension "diversity" includes female presence on the company's Board of Directors. More specifically, if one third of the board of directors in a company consists of female executives, it is considered as strength for the dimension diversity and lack of female executives can be considered as a concern. We use KLD social ratings from January 1991 to December 2009 in order to compare the results with those in Shalchian et al. (2015).

\section{Method}

In this study, we use the portfolio returns in Shalchian et al. (2015). Therefore, our data consists of mutually exclusive portfolios in mutually exclusive industries based on three dimensions of social responsibility (environment, employees' relation and community involvement) in order to measure and to compare the exposure of socially responsible portfolios and their conventional counterparts to the liquidity risk factor. Our three industries consist of mining, manufacturing and services. The mining industry includes all companies with SIC codes 1000 to 1499 (mining and chemicals) plus companies with SIC codes from 2800 to 2899 (manufacturing chemicals) and those with SIC codes 2900 to 2999 (petroleum products and coal). Our manufacturing industry consists of all companies with SIC codes 2000 to 3999 (manufacturing industry) excluding all companies with SIC codes from 2800 to 2899 and from 2900 to 2999. Our service industry regroups all companies with SIC codes 7000 to 8999 (service industry), 5100 to 5299 (wholesale industry) and 5300 to 5999 (retail industry).

In each industry, social ratings for each dimension of CSP consist of the arithmetic average of strengths minus the arithmetic average of concerns. Firms 
are classified in each industry respectively based on their environmental, employees' relation and community involvement performance rated by KLD. Consequently, our portfolios consist of "best-in-class" (high ranked) value-weighted portfolios with the highest $25 \%$ of companies and "worst-in-class" (low ranked) portfolios with the lowest $25 \%$ of companies. We then compare the exposure of best-in-class portfolios with those of their worst-in-class counterparts to the liquidity risk factor. Thus, following Shalchian et al. (2015), in each industry, we use "environment-sorted", "employee-sorted" and "community-sorted" portfolios.

Further, we use a five-factor regression model in which independent variables consist of those in Carhart's (1997) four-factor model plus a liquidity factor (Volume turnover) in Pastor and Stambault (2003) for all portfolios in the three industries:

$$
\begin{aligned}
R_{i, t}-R_{f, t}= & \alpha_{i}+\beta_{i, 1}\left(R_{m, t}-R_{f, t}\right)+\beta_{i, 2} S M B_{t} \\
& +\beta_{i, 3} H M L_{t}+\beta_{i, 4} P Y 1 Y R_{t}+\beta_{i, 5} L I Q_{t}+\varepsilon_{i, t}
\end{aligned}
$$

where the dependent variable, $R_{i, t}-R_{f, t}$ is the monthly excess return on portfolio $i$ over the risk-free rate in month t. $R_{m, t}-R_{f, t}$ denotes the excess return of the market portfolio over the risk-free rate, $S M B$ is the return of a portfolio of small-cap stocks minus the return of a portfolio of large-cap stocks, $H M L$ is the difference between the returns of a portfolio of high and a low book-to-market stocks. The Momentum factor $P R 1 Y R$ is constructed as the return of firms with the highest eleven-month returns lagged one month minus lowest eleven-month returns lagged one month. LIQ denotes Pastor and Stambault's liquidity factor, which consists of an equally-weighted liquidity measure of individual stocks on NYSE and AMEX. The error term in the regression is $\varepsilon_{i, t}$. We use Fama and French's (1993) market proxy as a relevant benchmark. The intercept $(\alpha)$ is an indicator of a performance differential between socially responsible and conventional investments and the coefficient $\beta_{i, 5}$ represents the sensitivity of the returns to the liquidity risk factor.

\section{Results}

Table 1 summarizes descriptive statistics for our portfolios for the 1991-2009 period. The table shows that in most cases, Sharpe ratios are higher for best-in-class portfolios. First, we notice that in the mining industry, $S p$ is respectively $0.73,0.83$ and 0.78 for high ranked environment-sorted, employee-sorted and community-sorted portfolios. Second, we note that in the manufacturing industry, Sharpe ratio is respectively 0.74 and 0.77 for high ranked environment and employee-sorted portfolios. The results suggest that even after adjusting for risk, high ranked portfolios perform better than their low ranked counterparts. The skewness and Kurtosis tests indicate only weak deviations from a normal distribution. Overall, our primary results suggest that high ranked portfolios excess returns, adjusted for volatility, are superior to those of low ranked portfolios. 
Table 1. Descriptive Statistics for socially-ranked portfolios, January 1991-December 2009. The Best-in-class and the Worst-in-class portfolios represent respectively the high-ranked and the low-ranked portfolios, according to KLD social ratings.

\begin{tabular}{|c|c|c|c|c|c|}
\hline Portfolio & Mean (\%) & Std.Dev (\%) & Sharpe ratio & Skewness & Kurtosis \\
\hline \multicolumn{6}{|l|}{ Mining } \\
\hline Best-in-class (environment) & 10.80 & 14.89 & 0.73 & -0.46 & 3.83 \\
\hline Worst-in-class (environment) & 9.60 & 16.28 & 0.59 & -0.59 & 3.96 \\
\hline Best-in-class (employee) & 12.10 & 14.55 & 0.83 & -0.21 & 3.19 \\
\hline Worst-in-class (employee) & 12.00 & 16.28 & 0.74 & -0.29 & 5.43 \\
\hline Best-in-class (community) & 10.80 & 13.86 & 0.78 & -0.38 & 3.43 \\
\hline Worst-in-class (community) & 12.00 & 16.30 & 0.76 & -0.29 & 3.72 \\
\hline \multicolumn{6}{|l|}{ Manufacturing } \\
\hline Best-in-class (environment) & 15.60 & 21.13 & 0.74 & -0.41 & 4.37 \\
\hline Worst-in-class (environment) & 12.00 & 19.05 & 0.63 & -0.08 & 7.76 \\
\hline Best-in-class (employee) & 14.40 & 18.71 & 0.77 & -0.21 & 3.19 \\
\hline Worst-in-class (employee) & 14.40 & 20.78 & 0.69 & -0.65 & 5.68 \\
\hline Best-in-class (community) & 12.00 & 18.01 & 0.67 & -0.41 & 4.37 \\
\hline Worst-in-class (community) & 18.00 & 18.71 & 0.96 & -0.25 & 4.33 \\
\hline \multicolumn{6}{|l|}{ Services } \\
\hline Best-in-class (environment) & 12.00 & 21.82 & 0.55 & 0.11 & 3.93 \\
\hline Worst-in-class (environment) & 18.00 & 25.98 & 0.69 & 0.80 & 5.73 \\
\hline Best-in-class (employee) & 13.20 & 21.82 & 0.60 & -0.31 & 3.66 \\
\hline Worst-in-class (employee) & 9.60 & 16.63 & 0.58 & -0.45 & 3.87 \\
\hline Best-in-class (community) & 9.60 & 20.44 & 0.47 & 0.28 & 5.07 \\
\hline Worst-in-class (community) & 13.20 & 22.52 & 0.59 & 0.17 & 5.17 \\
\hline
\end{tabular}

Note: This table is based on Shalchian et al. (2015).

Table 2 presents evaluation results using a five-factor model in the mining industry. Since the focus of this paper is the exposure differentials to the liquidity risk factor between high-ranked and low-ranked portfolios, we provide the results in "difference" portfolios. The difference of the coefficients' betas represents the degree of exposure of the portfolio to the liquidity risk factors. First, we note that community-sorted portfolios are the only ones to have a significant difference of exposure to the market factor. Furthermore, we notice that factor loading on LIQ is mainly significant. The results show a difference of -0.15 for environment-sorted and -0.25 for employee-sorted portfolios and $t$-statistics show that the results are statistically significant at $10 \%$. As for community-sorted portfolios, the difference is -0.22 and according to $t$-statistics, the result is statistically significant at $1 \%$. Overall, our results suggest that high-ranked mining companies seem to be less exposed to the liquidity risk factor relative to their low-ranked counterparts. The factor loading on $L I Q$ suggests 
Table 2. Empirical results of five-factor regressions on value-weighted portfolios in mining industry, January 1991-December 2009. Best-in-class and the worst-in-class portfolios represent respectively high-ranked and low-ranked portfolios according to KLD social ratings in each industry. $T$-statistics are in parenthesis. Sample alphas are annualized percentages. The regressions use Newey-West (1987) heteroskedasticity and autocorrelation consistent standard errors to calculate the significance levels for all coefficients.

\begin{tabular}{|c|c|c|c|c|c|c|c|}
\hline Portfolio & $\alpha(\%)$ & $R_{m}-R_{f}$ & $S M B$ & $H M L$ & $P Y \backslash Y R$ & $L I Q$ & $\operatorname{Adj} R^{2}$ \\
\hline $\begin{array}{l}\text { Best-in-class } \\
\text { (environment) }\end{array}$ & $\begin{array}{l}4.80^{* *} \\
(2.44)\end{array}$ & $\begin{array}{l}0.72^{* * *} \\
(9.85)\end{array}$ & $\begin{array}{l}-0.43^{* * *} \\
(-6.75)\end{array}$ & $\begin{array}{l}0.18^{\star} \\
(1.76)\end{array}$ & $\begin{array}{c}0.06 \\
(1.34)\end{array}$ & $\begin{array}{l}-0.05 \\
(-0.73)\end{array}$ & 0.47 \\
\hline $\begin{array}{l}\text { Worst-in-class } \\
\text { (environment) }\end{array}$ & $\begin{array}{l}6.00^{* *} \\
(2.55)\end{array}$ & $\begin{array}{l}0.70^{* * *} \\
(9.30)\end{array}$ & $\begin{array}{l}-0.39^{* * *} \\
(-4.11)\end{array}$ & $\begin{array}{l}0.20^{* *} \\
(1.98)\end{array}$ & $\begin{array}{c}0.30 \\
(0.47)\end{array}$ & $\begin{array}{l}0.10^{*} \\
(1.68)\end{array}$ & 0.41 \\
\hline Difference PF & $\begin{array}{l}-1.20 \\
(-0.44)\end{array}$ & $\begin{array}{c}0.02 \\
(0.18)\end{array}$ & $\begin{array}{l}-0.04 \\
(-0.20)\end{array}$ & $\begin{array}{l}-0.03 \\
(-0.25)\end{array}$ & $\begin{array}{c}0.03 \\
(0.43)\end{array}$ & $\begin{array}{l}-0.15^{*} \\
(-1.91)\end{array}$ & 0.01 \\
\hline $\begin{array}{l}\text { Best-in-class } \\
\text { (employee) }\end{array}$ & $\begin{array}{l}7.20^{* * *} \\
(3.89)\end{array}$ & $\begin{array}{l}0.76^{* * *} \\
(9.47)\end{array}$ & $\begin{array}{l}-0.44^{* * *} \\
(-6.51)\end{array}$ & $\begin{array}{l}-0.41 \\
(-6.91)\end{array}$ & $\begin{array}{c}0.04 \\
(0.83)\end{array}$ & $\begin{array}{l}-0.07 \\
(-1.55)\end{array}$ & 0.58 \\
\hline $\begin{array}{c}\text { Worst-in-class } \\
\text { (employee) }\end{array}$ & $\begin{array}{l}4.80^{*} \\
(1.91)\end{array}$ & $\begin{array}{l}0.81^{\star * *} \\
(11.72)\end{array}$ & $\begin{array}{l}-0.14^{* *} \\
(-2.14)\end{array}$ & $\begin{array}{c}0.36^{\star * *} \\
(4.34)\end{array}$ & $\begin{array}{l}-0.01 \\
(-0.15)\end{array}$ & $\begin{array}{l}0.18^{\star *} \\
(2.21)\end{array}$ & 0.54 \\
\hline Difference PF & $\begin{array}{c}2.40 \\
(0.44)\end{array}$ & $\begin{array}{l}-0.05 \\
(-0.18)\end{array}$ & $\begin{array}{c}-0.30^{\star * *} \\
(-2.69)\end{array}$ & $\begin{array}{l}-0.05 \\
(0.20)\end{array}$ & $\begin{array}{c}0.05 \\
(0.43)\end{array}$ & $\begin{array}{l}-0.25^{\star} \\
(1.91)\end{array}$ & 0.02 \\
\hline $\begin{array}{l}\text { Best-in-class } \\
\text { (community) }\end{array}$ & $\begin{array}{l}8.40^{* * *} \\
(4.17)\end{array}$ & $\begin{array}{l}0.64^{* * *} \\
(8.19)\end{array}$ & $\begin{array}{c}-0.48^{* * *} \\
(-7.25)\end{array}$ & $\begin{array}{c}0.02 \\
(0.23)\end{array}$ & $\begin{array}{c}0.05 \\
(0.86)\end{array}$ & $\begin{array}{l}-0.11^{\star *} \\
(-2.17)\end{array}$ & 0.50 \\
\hline $\begin{array}{l}\text { Worst-in-class } \\
\text { (community) }\end{array}$ & $\begin{array}{l}6.00^{* * *} \\
(3.24)\end{array}$ & $\begin{array}{l}0.78^{\star * *} \\
(10.93)\end{array}$ & $\begin{array}{c}-0.37^{* * *} \\
(-4.12)\end{array}$ & $\begin{array}{c}0.19 \\
(1.63)\end{array}$ & $\begin{array}{c}0.05 \\
(0.69)\end{array}$ & $\begin{array}{l}0.11^{* *} \\
(2.13)\end{array}$ & 0.51 \\
\hline Difference PF & $\begin{array}{c}2.40 \\
(0.97)\end{array}$ & $\begin{array}{l}-0.14^{* *} \\
(-2.08)\end{array}$ & $\begin{array}{l}-0.11 \\
(-0.90)\end{array}$ & $\begin{array}{l}-0.17 \\
(-1.33)\end{array}$ & $\begin{array}{c}0.00 \\
(1.41)\end{array}$ & $\begin{array}{c}-0.22^{\star * *} \\
(-3.38)\end{array}$ & 0.07 \\
\hline
\end{tabular}

${ }^{\star}$ Significant at the 10 percent level. ${ }^{*}$ Significant at the 5 percent level. ${ }^{* *}$ Significant at the 1 percent level.

that in the mining industry, for the three dimensions, environment, employee and community, worst-in-class portfolios are tilted towards companies with high sensitivity to a liquidity factor. Overall, our results suggest that in the mining industry socially responsible investments seem to be relatively less exposed to the liquidity risk factor.

Table 3 presents evaluation results using a five-factor model in the manufacturing industry. First, we note that best-in-class portfolios show a higher average factor-adjusted annual return for an environment-sorted portfolio. Our results confirm those in Shalchian et al. (2015) who suggested that environment seems to be an important factor in the manufacturing industry. Further, we notice that there is no significant difference for factor loading on $L I Q$ for environment and community-sorted portfolios. Our results suggest that in the manufacturing industry, socially responsible investments based on environment and community do not seem to be exposed to the liquidity risk factor. As for employee-sorted portfolios, we note a difference of 0.08 in favor of best-in-class portfolio and according to $t$-statistics the result is statistically significant at $10 \%$. Our results suggest that in the manufacturing industry, the best-in-class employee-sorted 
Table 3. Empirical results of five-factor regressions on value-weighted portfolios in manufacturing industry, January 1991-December 2009. Best-in-class and the worst-in-class portfolios represent respectively high-ranked and low-ranked portfolios according to KLD social ratings in each industry. $T$-statistics are in parenthesis. Sample alphas are annualized percentages. The regressions use Newey-West (1987) heteroskedasticity and autocorrelation consistent standard errors to calculate the significance levels for all coefficients.

\begin{tabular}{|c|c|c|c|c|c|c|c|}
\hline Portfolio & $\alpha(\%)$ & $R_{m}-R_{f}$ & $S M B$ & $H M L$ & $P Y 1 Y R$ & $L I Q$ & Adj $R^{2}$ \\
\hline $\begin{array}{l}\text { Best-in-class } \\
\text { (environment) }\end{array}$ & $\begin{array}{c}10.80^{\star * *} \\
(4.18)\end{array}$ & $\begin{array}{l}1.02^{* * *} \\
(23.33)\end{array}$ & $\begin{array}{c}0.05 \\
(0.43)\end{array}$ & $\begin{array}{c}-0.31^{\star * \star} \\
(-5.09)\end{array}$ & $\begin{array}{l}-0.15^{\star *} \\
(-2.55)\end{array}$ & $\begin{array}{c}0.06 \\
(0.94)\end{array}$ & 0.73 \\
\hline $\begin{array}{l}\text { Worst-in-class } \\
\text { (environment) }\end{array}$ & $\begin{array}{l}3.60^{*} \\
(1.68)\end{array}$ & $\begin{array}{l}1.02^{* * *} \\
(22.72)\end{array}$ & $\begin{array}{c}0.03 \\
(0.35)\end{array}$ & $\begin{array}{c}0.59^{* * *} \\
(6.77)\end{array}$ & $\begin{array}{c}-0.19^{* * *} \\
(-2.71)\end{array}$ & $\begin{array}{c}0.06 \\
(1.44)\end{array}$ & 0.77 \\
\hline Difference PF & $\begin{array}{l}7.20^{\star *} \\
(2.01)\end{array}$ & $\begin{array}{c}0.00 \\
(0.02)\end{array}$ & $\begin{array}{c}0.02 \\
(0.10)\end{array}$ & $\begin{array}{c}0.28^{* * *} \\
(7.62)\end{array}$ & $\begin{array}{c}0.04 \\
(0.35)\end{array}$ & $\begin{array}{c}0.00 \\
(0.06)\end{array}$ & 0.37 \\
\hline $\begin{array}{l}\text { Best-in-class } \\
\text { (employee) }\end{array}$ & $\begin{array}{c}7.20^{\star * *} \\
(4.24)\end{array}$ & $\begin{array}{l}1.07^{* * *} \\
(35.55)\end{array}$ & $\begin{array}{l}0.10^{* *} \\
(2.18)\end{array}$ & $\begin{array}{c}-0.29^{\star * *} \\
(-4.81)\end{array}$ & $\begin{array}{c}-0.08^{\star * *} \\
(-2.93)\end{array}$ & $\begin{array}{l}0.11^{\star} \\
(1.71)\end{array}$ & 0.80 \\
\hline $\begin{array}{c}\text { Worst-in-class } \\
\text { (employee) }\end{array}$ & $\begin{array}{c}7.20^{\star * *} \\
(3.59)\end{array}$ & $\begin{array}{l}1.03^{\star * *} \\
(22.16)\end{array}$ & $\begin{array}{c}0.20^{* * *} \\
(3.28)\end{array}$ & $\begin{array}{c}0.09 \\
(1.05)\end{array}$ & $\begin{array}{l}-0.14^{\star * *} \\
(-4.17)\end{array}$ & $\begin{array}{c}0.03 \\
(0.70)\end{array}$ & 0.80 \\
\hline Difference PF & $\begin{array}{c}0.00 \\
(0.28)\end{array}$ & $\begin{array}{c}0.04 \\
(0.98)\end{array}$ & $\begin{array}{l}-0.10 \\
(-1.25)\end{array}$ & $\begin{array}{l}-0.20^{\star * *} \\
(-3.58)\end{array}$ & $\begin{array}{c}0.06 \\
(1.10)\end{array}$ & $\begin{array}{l}0.08^{\star} \\
(1.74)\end{array}$ & 0.14 \\
\hline $\begin{array}{l}\text { Best-in-class } \\
\text { (community) }\end{array}$ & $\begin{array}{c}7.20^{\star * *} \\
(3.52)\end{array}$ & $\begin{array}{l}0.90^{* * *} \\
(16.95)\end{array}$ & $\begin{array}{l}-0.08 \\
(1.18)\end{array}$ & $\begin{array}{l}-0.11^{\star \star} \\
(-2.41)\end{array}$ & $\begin{array}{l}-0.17^{\star * *} \\
(-3.87)\end{array}$ & $\begin{array}{l}-0.00 \\
(-0.00)\end{array}$ & 0.78 \\
\hline $\begin{array}{l}\text { Worst-in-class } \\
\text { (community) }\end{array}$ & $\begin{array}{c}9.60^{\star * *} \\
(3.34)\end{array}$ & $\begin{array}{l}1.09^{* * \star} \\
(31.50)\end{array}$ & $\begin{array}{c}0.01 \\
(0.08)\end{array}$ & $\begin{array}{c}0.08 \\
(0.68)\end{array}$ & $\begin{array}{c}0.02 \\
(0.46)\end{array}$ & $\begin{array}{c}0.02 \\
(0.50)\end{array}$ & 0.75 \\
\hline Difference PF & $\begin{array}{l}-2.40 \\
(-0.82)\end{array}$ & $\begin{array}{l}-0.19^{* *} \\
(-2.38)\end{array}$ & $\begin{array}{c}0.09 \\
(0.88)\end{array}$ & $\begin{array}{l}-0.19 \\
(-1.32)\end{array}$ & $\begin{array}{c}-0.19^{* * *} \\
(-2.65)\end{array}$ & $\begin{array}{l}-0.02 \\
(-0.47)\end{array}$ & 0.07 \\
\hline
\end{tabular}

${ }^{\star}$ Significant at the 10 percent level. ${ }^{\star}$ Significant at the 5 percent level. ${ }^{* *}$ Significant at the 1 percent level.

portfolio is tilted towards companies with relatively higher sensitivity to the liquidity factor. In other words, socially responsible investment based on employees' welfare in the manufacturing industry shows a relatively high exposure to the liquidity risk factor.

Table 4 presents the performance estimates in the service industry. First, we note that for employee-sorted portfolios, the gap between average factor-adjusted annual returns is $3.60 \%$ and the difference is statistically significant at $10 \%$. As for environment-sorted and community sorted portfolios, average returns of best-in-class portfolios are not significantly higher than their worst-in-class counterparts. However, the differences in $L I Q$ coefficients are mainly in favor of best-in-class. The results show differences of 0.24 and 0.12 for the environment and employee-sorted portfolios respectively; $t$-statistics show that the results are statistically significant at $5 \%$ and $10 \%$. Our results show that in the service industry and based on environment and employees' relation, the socially responsible companies seem to be tilted toward relatively liquidity-sensitive companies. In other words, our results suggest that in the service industry, socially responsible investments based on environment and employees' relation seem to show a relatively higher degree of exposure to the liquidity risk factor. 
Table 4. Empirical results of five-factor regressions on value-weighted portfolios in service industry, January 1991-December 2009. Best-in-class and the worst-in-class portfolios represent respectively high-ranked and low-ranked portfolios according to KLD social ratings in each industry. $T$-statistics are in parenthesis. Sample alphas are annualized percentages. The regressions use Newey-West (1987) heteroskedasticity and autocorrelation consistent standard errors to calculate the significance levels for all coefficients.

\begin{tabular}{|c|c|c|c|c|c|c|c|}
\hline Portfolio & $\alpha(\%)$ & $R_{m}-R_{f}$ & $S M B$ & $H M L$ & $P Y \backslash Y R$ & $L I Q$ & $\operatorname{Adj} R^{2}$ \\
\hline $\begin{array}{l}\text { Best-in-class } \\
\text { (environment) }\end{array}$ & $\begin{array}{l}8.40^{* *} \\
(2.25)\end{array}$ & $\begin{array}{l}0.97^{* * *} \\
(15.89)\end{array}$ & $\begin{array}{c}-0.31^{\star * *} \\
(-3.10)\end{array}$ & $\begin{array}{c}-0.40^{* * *} \\
(-4.46)\end{array}$ & $\begin{array}{c}-0.20^{* * *} \\
(-3.47)\end{array}$ & $\begin{array}{l}0.19^{* *} \\
(2.48)\end{array}$ & 0.64 \\
\hline $\begin{array}{l}\text { Worst-in-class } \\
\text { (environment) }\end{array}$ & $\begin{array}{l}13.20^{* *} \\
(2.31)\end{array}$ & $\begin{array}{l}0.87^{* * *} \\
(5.74)\end{array}$ & $\begin{array}{c}0.04 \\
(0.26)\end{array}$ & $\begin{array}{c}-0.48^{* * *} \\
(-4.13)\end{array}$ & $\begin{array}{c}0.08 \\
(0.60)\end{array}$ & $\begin{array}{l}-0.05 \\
(-0.40)\end{array}$ & 0.36 \\
\hline Difference PF & $\begin{array}{l}-4.80 \\
(-0.54)\end{array}$ & $\begin{array}{c}0.10 \\
(0.57)\end{array}$ & $\begin{array}{l}-0.27^{* *} \\
(-1.98)\end{array}$ & $\begin{array}{c}0.05 \\
(0.47)\end{array}$ & $\begin{array}{l}-0.12^{*} \\
(-1.71)\end{array}$ & $\begin{array}{l}0.24^{* *} \\
(2.02)\end{array}$ & 0.08 \\
\hline $\begin{array}{l}\text { Best-in-class } \\
\text { (employee) }\end{array}$ & $\begin{array}{l}8.40^{* * *} \\
(3.10)\end{array}$ & $\begin{array}{l}1.01^{* * *} \\
(13.43)\end{array}$ & $\begin{array}{l}-0.10 \\
(-0.92)\end{array}$ & $\begin{array}{c}-0.44^{\star * *} \\
(-4.54)\end{array}$ & $\begin{array}{l}-0.08 \\
(-1.21)\end{array}$ & $\begin{array}{l}0.12^{\star} \\
(1.68)\end{array}$ & 0.68 \\
\hline $\begin{array}{l}\text { Worst-in-class } \\
\text { (employee) }\end{array}$ & $\begin{array}{l}4.80^{*} \\
(1.83)\end{array}$ & $\begin{array}{l}0.69^{* * *} \\
(7.70)\end{array}$ & $\begin{array}{c}0.24 \\
(0.26)\end{array}$ & $\begin{array}{c}0.05 \\
(0.38)\end{array}$ & $\begin{array}{l}-0.13^{*} \\
(-1.67)\end{array}$ & $\begin{array}{c}0.00 \\
(0.01)\end{array}$ & 0.48 \\
\hline Difference PF & $\begin{array}{l}3.60^{*} \\
(1.87)\end{array}$ & $\begin{array}{l}0.34^{* * *} \\
(2.84)\end{array}$ & $\begin{array}{l}-0.14 \\
(-1.30)\end{array}$ & $\begin{array}{c}-0.49^{* * *} \\
(-2.83)\end{array}$ & $\begin{array}{c}0.05 \\
(0.53)\end{array}$ & $\begin{array}{l}0.12^{\star} \\
(1.67)\end{array}$ & 0.21 \\
\hline $\begin{array}{l}\text { Best-in-class } \\
\text { (community) }\end{array}$ & $\begin{array}{l}7.20^{* *} \\
(2.12)\end{array}$ & $\begin{array}{l}0.89^{* * *} \\
(12.01)\end{array}$ & $\begin{array}{l}-0.09 \\
(-0.89)\end{array}$ & $\begin{array}{c}-0.31^{\star * *} \\
(-4.17)\end{array}$ & $\begin{array}{c}-0.25^{\star * *} \\
(-2.67)\end{array}$ & $\begin{array}{c}0.10 \\
(1.64)\end{array}$ & 0.64 \\
\hline $\begin{array}{l}\text { Worst-in-class } \\
\text { (community) }\end{array}$ & $\begin{array}{l}9.60^{* *} \\
(2.54)\end{array}$ & $\begin{array}{l}0.80^{* * *} \\
(7.94)\end{array}$ & $\begin{array}{l}0.38^{* * *} \\
(3.26)\end{array}$ & $\begin{array}{c}-0.29^{* * *} \\
(-3.51)\end{array}$ & $\begin{array}{l}-0.13 \\
(-1.18)\end{array}$ & $\begin{array}{l}-0.01 \\
(-0.15)\end{array}$ & 0.52 \\
\hline Difference PF & $\begin{array}{l}-2.40 \\
(-0.76)\end{array}$ & $\begin{array}{c}0.09 \\
(0.64)\end{array}$ & $\begin{array}{c}-0.47^{* * *} \\
(-3.48)\end{array}$ & $\begin{array}{l}-0.02 \\
(-0.24)\end{array}$ & $\begin{array}{l}-0.12 \\
(-1.30)\end{array}$ & $\begin{array}{c}0.11 \\
(1.10)\end{array}$ & 0.10 \\
\hline
\end{tabular}

${ }^{*}$ Significant at the 10 percent level. ${ }^{*}$ Significant at the 5 percent level. ${ }^{* *}$ Significant at the 1 percent level.

\section{Conclusion}

In this paper, we analyzed whether socially responsible investments are also subject to the liquidity risk factor as well as other risk factors. Supposing that investors consider different dimensions of CSP separately in their decision-making process, we used Shalchian et al. (2015) screened portfolios based on environment, employees' relation and community involvement and in three different industries. First, our results suggest that, in most cases, socially responsible portfolios performed better than their conventional counterparts. The results confirm those of Griffin and Mahon (1997) and Shalchian et al. (2015) who suggested that different dimensions of social responsibility seem to have a different relation with financial performance in different industries.

Second, results also show that the relation social-financial performance in the three industries and based on the three dimensions can be affected differently by the liquidity risk factor. Using Pastor and Stambault's (2003) liquidity risk factor, we presented evidence that in the mining industry for environment, employee and community-sorted portfolios, worst-in-class portfolios seem to be tilted towards companies with relatively higher sensitivities to the liquidity factor. Our findings suggest that socially responsible investments in the mining in- 
dustry show a relatively lower exposure to the liquidity risk factor. Further, our results also suggest that in the manufacturing industry, except for employee-sorted portfolios, socially responsible and conventional investments show no significant exposure to the liquidity risk factor. However, best-in-class portfolios seem to be tilted towards companies with relatively higher sensitivity to the liquidity risk factor for employee-sorted portfolios. Finally, in the service industry, for environment and employee-sorted portfolios, the best-in-class portfolio seems to be tilted towards companies with a higher degree of sensitivity to the liquidity risk factor. In fact, our findings suggest that in the manufacturing industry, based on employees' relation and in the service industry based on environment and employees' relation, socially responsible investments show a relatively higher exposure to the liquidity risk factor.

\section{References}

Bauer, R., Derwall, J., \& Hann, D. (2009). Employees Relation and Credit Risk. http://www.ssrn.com-1483112

Bouslah, K., Kryzanowski, L., \& M'Zali, B. (2013). The Impact of the Dimensions of Social Performance on Firm Risk. Journal of Banking \& Finance, 37, 1258-1273. https://doi.org/10.1016/j.jbankfin.2012.12.004

Brennan, M. J., \& Subrahmanyan, A. (1996). Market Microstructure and Asset Pricing: On the Compensation for Illiquidity of Stock Return. Journal of Financial Economics, 41, 441-464. https://doi.org/10.1016/0304-405X(95)00870-K

Carhart, M. M. (1997). On Persistence in Mutual Fund Performance. Journal of Finance, 52, 57-82. https://doi.org/10.1111/j.1540-6261.1997.tb03808.x

Chordia, T., Subrahmanyan, A., \& Anshuman, V. R. (2001). Trading Activity and Expected Stock Return. Journal of Financial Economics, 59, 3-32. https://doi.org/10.1016/S0304-405X(00)00080-5

Chung, S. Y., Eneroth, K., \& Schneeweis, T. (2003). Corporate Reputation and Investment Performance: The UK and US Experience. Research in International Business and Finance, 17, 273-291.

Cohen, M. A., Fenn, S. A., \& Konar, S. (1997). Environmental and Financial Performance: Are They Related? Working Paper, Vanderbilt University.

Derwall, J., Guestner, N., Bauer, R., \& Koedijk, K. (2005). The Eco-Efficiency Premium Puzzle. The Financial Analysts Journal, 61, 51-61. https://doi.org/10.2469/faj.v61.n2.2716

Eisfeldt, A. (2002). Endogenous Liquidity in Asset Markets. Working Paper Extension III, Northwestern University.

El Ghoul, S., Guedhami, O., Kwok, C. Y., \& Mishra, D. R. (2011). Does Corporate Social Responsibility Affect the Cost of Capital? Journal of Banking \& Finance, 35, 2388-2406. https://doi.org/10.1016/j.jbankfin.2011.02.007

Fiori, F. (2000). Liquidity Premia in the Equity Market: An Investigation into the Characteristics of Liquidity and Trading Activity. Working Paper, Chicago, IL: Chicago University.

Goss, A. (2012). Corporate Social Performance and Idiosyncratic Risk: A Variance Decomposition Analysis. In Midwest Finance Association Annual Meeting. Midwest Finance Association. 
Goss, A., \& Roberts, G. R. (2011). The Impact of Corporate Social Responsibility on the Cost of Bank Loans. Journal of Banking \& Finance, 35, 1794-1810. https://doi.org/10.1016/j.jbankfin.2010.12.002

Griffin, J. J., \& Mahon, J. F. (1997). The Corporate Social Performance and Corporate Financial Performance Debate: Twenty-Five Years of Incomparable Research. Business and Society, 36, 5-31. https://doi.org/10.1177/000765039703600102

Harrisson, J. S., \& Freeman, E. W. (1999). Stakeholders, Social Responsibility and Performance: Empirical Evidence and Theoretical Perspectives. Academy of Management Journal, 42, 479-485.

Holmstrom, B., \& Triole, J. (2001). LAPM: A Liquidity-Based Asset Pricing Model. The Journal of Finance, 56, 1837-1867. https://doi.org/10.1111/0022-1082.00391

Huberman, G., \& Halka, D. (2001). Systematic Liquidity. Journal of Financial Research, 24, 161-178. https://doi.org/10.1111/j.1475-6803.2001.tb00763.x

Kempf, A., \& Osthoff, P. (2007). The Effect of Socially Responsible Investing on Portfolio Performance. European Financial Management, 13, 908-922.

https://doi.org/10.1111/j.1468-036X.2007.00402.x

Lee, D. D., \& Faff, R. W. (2009). Corporate Sustainability Performance and Idiosyncratic Risk: A Global Perspective. Financial Review, 44, 213-237. https://doi.org/10.1111/j.1540-6288.2009.00216.x

Lo, L. W., \& Wang, J. (2000). Trading Volume: Definitions, Data Analysis, and Implications of Portfolio Theory. The Review of Financial Studies, 13, 257-300.

https://doi.org/10.1093/rfs/13.2.257

Moore, G. (2001). Corporate Social and Financial Performance: An Investigation in U.K. Supermarket Industry. Journal of Business Ethics, 34, 299-315.

https://doi.org/10.1023/A:1012537016969

Pastor, L., \& Stambault, R. F. (2003). Liquidity Risk and Exposed Stock Return. Journal of Political Economy, 111, 642-685. https://doi.org/10.1086/374184

Robinson, M., Kleffner, A., \& Barrels, S. (2008). The Value of Reputation for Corporate Social Responsibility: Empirical Evidence. Working Paper, Ann Arbor, MI: University of Michigan.

Salama, A., Anderson, K., \& Toms, J. S. (2011). Does Community and Environmental Responsibility Affect Firm's Risk: Evidence from UK Panel Data, 1994-2006. Business Ethics: A European Review, 20, 192-204. https://doi.org/10.1111/j.1467-8608.2011.01617.x

Shalchian, H., Bouslah, K., \& M'Zali, B. (2015). A Multi-Dimensional Analysis of Corporate Social Responsibility: Different Signals in Different Industries. Journal of Financial Risk Management, 4, 90-107.

Shalchian, H., M'Zali, B., \& Paquet, A. (2014). A Theoretical Underpinning of the Relation between Corporate Social Performance and Stock Returns. Journal of Business and Economics, 5, 249-259. https://doi.org/10.15341/jbe(2155-7950)/12.05.2014/004

Shalchian, H., M'Zali, B., Elbadraoui, K., \& Lilti, J. J. (2012). On the Performance of Socially Responsible Investing: Further Evidence. Bankers, Markets and Investors, 112, 30-42.

Simpson, W. G., \& Kohers, T. (2002). The Link between Corporate Social and Financial Performance: Evidence from Banking Industry. Journal of Business Ethics, 35, 97-109. https://doi.org/10.1023/A:1013082525900

Stanwick, P. A., \& Stanwick, S. D. (1998). The Relation between Corporate Social Performance and Organizational Size, Financial Performance, and Environmental Per- 
formance: An Empirical Examination. Journal of Business Ethics, 17, 195-204. https://doi.org/10.1023/A:1005784421547

Starks, L. T. (2009). EFA Keynote Speech: "Corporate Governance and Corporate Social Responsibility: What Do Investors Care about? What Should Investors Care about?" Financial Review, 44, 461-468. https://doi.org/10.1111/j.1540-6288.2009.00225.x

Waddock, S., \& Graves, S. B. (1997). The Corporate Social Performance-Financial Performance Link. Strategic Management Journal, 18, 303-327. https://doi.org/10.1002/(SICI)1097-0266(199704)18:4<303::AID-SMJ869>3.0.CO;2-G

Yamashita, R., Miwaka, S., Sen, S., \& Robers, M. C. (1999). The Rewards of Environmental Conscientiousness Is U.S. Capital Market. Journal of Financial and Strategic Decision, 12, 73-82. 